\title{
Determinants Of Multidrug Resistant Tuberculosis Among Adultsundergoing Treatment For Tuberculosis In Tigray Region, Ethiopia: A Case Control Study
}

Research article

Keywords:

Posted Date: November 2nd, 2020

DOI: https://doi.org/10.21203/rs.2.15772/v3

License: (1) This work is licensed under a Creative Commons Attribution 4.0 International License.

Read Full License 


\section{Abstract}

The authors have requested that this preprint be withdrawn due to author disagreement.

\section{Full Text}

The authors have withdrawn this preprint from Research Square. 